Analía Laura Giménez* and Mauro Ignacio Schiaffini

\title{
Patagonian bats: new size limits, southernmost localities and updated distribution for Lasiurus villosissimus and Myotis dinellii (Chiroptera: Vespertilionidae)
}

https://doi.org/10.1515/mammalia-2019-0024

Received March 10, 2019; accepted June 7, 2019; previously published online July 16, 2019

Abstract: Vespertilionid species are widely distributed in South America. They are highly diverse, with physiological and behavioral adaptations which allow them to extend their distributions into temperate areas. In Patagonia, this family is represented by seven species in three genera (Histiotus, Lasiurus and Myotis). In this study, we analyzed the distribution of two vespertilionid species, Lasiurus villosissimus and Myotis dinellii, including new southernmost records, and their relationship with environmental variables. Two different spatial scales were analyzed: a continental approach for species distribution analyses (South America), and local trapping of bats in northwestern Chubut province, Argentina. We present new southern limits for L. villosissimus and $M$. dinellii, and included new records for Patagonian bats. The big hoary bat $L$. villosissimus was recorded as the largest bat inhabiting Patagonia, relating it as a bat mainly inhabiting low, humid and temperate/warm areas. The little yellow bat $M$. dinellii, instead, is the smallest mammal and the smallest bat recorded in Patagonia to date, related mainly with dry, mid-altitude and temperate/warm areas.

Keywords: big hoary bat; geographic limits; little yellow bat; Patagonia.

\section{Introduction}

Understanding species' geographic distributions is one of the main goals in ecology (Humpries et al. 2002). The distribution of a species is related to a number of biotic

\footnotetext{
*Corresponding author: Analía Laura Giménez, Centro de Investigación Esquel de Montaña y Estepa Patagónica (CIEMEP, CONICET-UNPSJB), Laboratorio de Investigaciones en Evolución y Biodiversidad (LIEB), Facultad de Ciencias Naturales y Ciencias de la Salud, UNPSJB, sede Esquel. Roca 780, CP 9200 Esquel, Chubut, Argentina, e-mail: al_gimenez@yahoo.com.ar

Mauro Ignacio Schiaffini: Centro de Investigación Esquel de Montaña y Estepa Patagónica (CIEMEP, CONICET-UNPSJB), Laboratorio de Investigaciones en Evolución y Biodiversidad (LIEB), Facultad de Ciencias Naturales y Ciencias de la Salud, UNPSJB, sede Esquel. Roca 780, CP 9200 Esquel, Chubut, Argentina
}

(i.e. intra and interspecific interactions) and abiotic factors (i.e. temperature, altitude, precipitation and productivity), together with dispersal ability capacities and the evolutionary history of each lineage (Gaston 2003, Cox and Moore 2005, Soberón and Peterson 2005). As abiotic factors are not evenly distributed in space or time, they shape the borders of species' distributions trough extreme values (e.g. minimum or maximum temperatures, dry or humid areas), which in turn influence resource availability and impose limits to reproduction and survival (Mackey and Lindenmayer 2001, Gaston 2003). In this way, those areas with more favorable abiotic (and biotic) conditions will show the highest relative abundance, while records will become more scarce and more far away from each other toward the borders of a species' distribution (Brown 2003 and references therein).

South American insectivorous bats are faced in their southern limits of distribution (i.e. Patagonia) with a series of environmental restrictions due mainly to minimum temperatures (Pearson and Pearson 1989), which are directly related to the availability of food resources. This resource availability is, in turn, one of the main determinants of bat communities (McNab 1982, Findley 1993, Aguirre et al. 2003), because it is considered as highly variable between seasons in temperate climates like those of Patagonia. Patagonian bats show a number of physiological traits (i.e. hibernation, daily torpor, migration and delayed fertilization; McNab 1982, Pearson and Pearson 1989, Stevens 2004) that allow their survival and reproduction. The analysis of localities in the borders of species' distributions is of great importance because it provides information on extreme climatic values affecting species distributional limits.

Only the families Molossidae and Vespertilionidae are recorded amongst Patagonian bats (Koopman 1982, Giménez 2014). Only two species of the Molossidae family are currently recorded: Tadarida brasiliensis (Geoffroy St.Hilaire 1824) as the most commonly found, and Eumops patagonicus Thomas 1924, with only one record (Monjeau et al. 1994). Species of Vespertilionidae are widely distributed in South America, and they are highly diverse with physiological and behavioral adaptations which allow them to extend their distributions into temperate areas (Stevens 2004). Vespertilionids in Patagonia are represented by 
seven species in three genera: Histiotus Gervais 1856, Lasiurus Gray 1831 and Myotis Kaup 1829. However, new records (Giménez 2010, Giménez et al.2012, Barquez et al.2013, Díaz et al. 2017) and taxonomic revisions (Novaes et al. 2018a,b) are constantly modifying the number of recorded species, and changing the austral limits of their distribution.

The taxonomy of the tribe Lasiurini within Vespertilionidae is being reviewed, and molecular studies suggest a split in three different genera: Lasiurus [red bats, e.g. Lasiurus blossevillii (Lesson 1826), Lasiurus varius Poeppig 1835], Aeorestes Fitzinger 1870 [hoary bats, e.g. Aeorestes cinereus (Palisot de Beauvois 1796)] and Dasypterus W. Peters 1870 [yellow bats, e.g. Dasypterus ega (Gervais 1856); Baird et al. 2015, 2017]. In the present work, however, we follow Ziegler et al. (2016) and Novaes et al. (2018b) and consider Aeorestes as a subgenus of Lasiurus. Molecular evidence also provided support to treat the subspecies Lasiurus cinereus villosissimus as a full species (Baird et al. 2015, 2017). So according to these studies, we considered Lasiurus villosissimus (É. Geoffroy St.-Hilaire 1806) as the hoary bat widely distributed in South America, in accordance with Teta et al. (2018). The big hoary bat L. villosissimus has its type locality in Paraguay (restricted to Asuncion by Cabrera 1958), and is widely distributed in South America, including records in different environments of Colombia, Venezuela, Ecuador, Paraguay, Peru, Chile, Bolivia, Uruguay, Argentina and southern Brazil (Baird et al. 2015, Díaz et al. 2016). The southernmost records to date are in $39^{\circ} \mathrm{S}$ in Argentina (Chimpay, Río Negro; Peracci and Perez 1999) and $41^{\circ} \mathrm{S}$ in Chile (Puerto Montt, Región de Los Lagos; Mann Fischer 1978).

The genus Myotis has a high diversity of over 110 extant species, with numerous and recent taxonomic reviews (see Wilson 2007, Moratelli and Wilson 2011, Moratelli et al. 2013, 2016, 2017, Novaes et al. 2018b). The little yellow bat Myotis dinellii Thomas 1902 has been treated as a subspecies of both Myotis chiloensis (Waterhouse 1840) and Myotis levis (I. Geoffroy St.-Hilaire 1824) (see Cabrera 1958, LaVal 1973, Barquez et al. 1999, Simmons 2005). We follow Miranda et al. (2013) who, using morphometric techniques and comparative analysis with $M$. levis, proposed to treat $M$. dinellii as a full species (see also Teta et al. 2018). The type locality of the little yellow bat is Tucumán (Tucumán province, Argentina) and its distribution encompasses Bolivia, Brazil and Argentina (Barquez 2006, Passos et al. 2010, Moratelli and Wilson 2011, Miranda et al. 2013). The southernmost locality recorded to date is in Neuquén province, and does not reach $39^{\circ} \mathrm{S}$ (Confluencia, Neuquén, Argentina; Barquez et al. 1999).

The aim of this work is to present an updated distribution analysis for these two vespertilionid species (Lasiurus villosissimus and Myotis dinellii), including new southernmost records, and analyze their relationship with environmental variables. New general information for several species of Patagonian bats is presented too.

\section{Materials and methods}

\section{Study area}

Following the objectives, two different spatial scales were analyzed: a continental approach for species distribution analyses (i.e. South America), and local trapping of bats in northwestern Chubut province, Argentina (i.e. Central Patagonia).

The climate of South America presents tropical, subtropical and extratropical areas due to the great latitudinal extension and orography (Garreaud et al. 2009). Two anticyclones affect precipitation patterns, with the South Pacific Anticyclone and the Andes mountains influencing the west-east rain gradient, while the Atlantic South Anticyclone carries humid winds to the center of the continent (Mancini et al. 2005). The temperature decreases from the Equator to the Poles, although anomalies can cause different temperatures at equivalent latitudes (Garreaud et al. 2009). Following the biogeographic scheme of Olson et al. (2001), South America is included within the Neotropical realm, with tropical and temperate forests, mangroves, grasslands and shrublands, and xeric formations (Dinerstein et al. 1995).

Bats were surveyed in two protected areas of northwestern Chubut (Argentina): Área Natural Protegida (ANP) Nant y Fall ( $\left.43^{\circ} 11^{\prime} 25^{\prime \prime} \mathrm{S}, 71^{\circ} 28^{\prime} 19^{\prime \prime} \mathrm{W}\right)$, and ANP Piedra Parada ( $42^{\circ} 38^{\prime} 30^{\prime \prime}$ S, $70^{\circ} 05^{\prime} 59^{\prime \prime}$ W, Figure 1).

Nant y Fall occurs within the Valdivian Temperate Forests (sensu Olson et al. 2001, Figure 1), an ecoregion characterized by temperate/cold and humid climate, with winter rains and snow, frost extending almost all year and strong westerlies (Burkart et al. 1999). The dominant trees are species of the genus Nothofagus (Nothofagus antarctica, Nothofagus dombeyi, Nothofagus pumilio; Nothofagacea), Austrocedrus chilensis (Cupressaceae), Fitzroya cupressoides (Cupressaceae), Embothrium coccineum (Proteaceae) and Lomatia hirsuta (Proteaceae). Among shrubs, Chusquea culeou (Poaceae), Fuchsia magellanica (Onagraceae) and Berberis microphylla (Berberidaceae) are usually found (Veblen and Lorenz 1988, León et al. 1998, Burkart et al. 1999).

Piedra Parada, instead, is found within the Patagonian steppe (sensu Olson et al. 2001; Figure 1), is an 


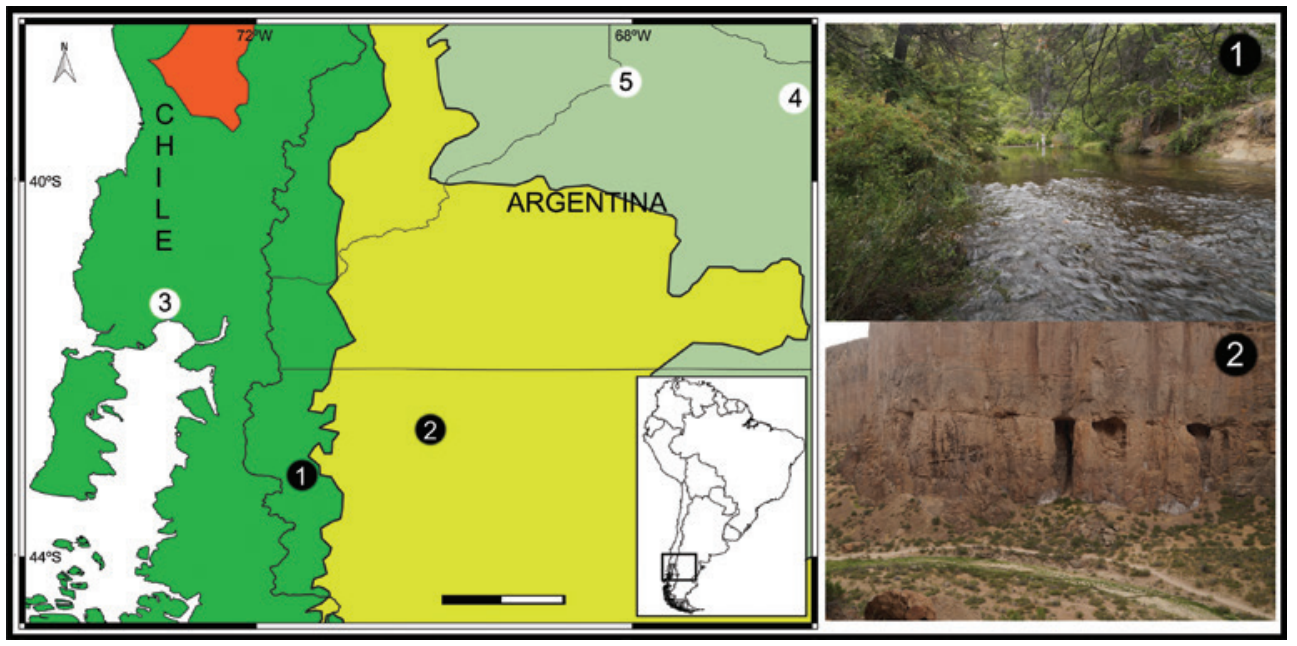

Figure 1: Map and images of protected areas sampled in NW Chubut province: (1) ANP Nant y Fall, (2) ANP Piedra Parada, (3) and (4) previous southernmost localities in Argentina and Chile for L. villosissimus; (5) previous southernmost locality for M. dinellii.

Ecoregions sensu Olson et al. (2001): Valdivian Temperate Forests (green); Patagonian Steppe (yellow); Low Monte (gray); Chilean Matorral (red). Scale (black and white bar) $=100 \mathrm{~km}$.

ecoregion characterized by a cold and dry climate (i.e. semi desert), with annual precipitation with an average of less than $250 \mathrm{~mm}$ and strong westerlies (Burkart et al. 1999). The most common vegetation are low shrubs such as Mulinum spinosum (Apiaceae), Senecio bracteolatus (Asteraceae), Berberis microphylla and Adesmia volckmannii (Fabaceae), and grasses such as Pappostipa humilis (Poaceae) and Festuca pallescens (Poaceae), among others (Veblen and Lorenz 1988, León et al. 1998, Paruelo et al. 1998, Burkart et al. 1999, Velasco and Siffredi 2009).

\section{Bat survey}

Bats were surveyed from December 2017 to February 2018, including five survey nights in each protected area. Five mist nets of $6 \mathrm{~m}$ long, $2 \mathrm{~m}$ wide and $38.1 \mathrm{~mm}$ of mesh were used each night, which were opened at dusk and kept open for ca. $5 \mathrm{~h}$. Captured specimens were measured, weighted and identified following Barquez et al. (1993, 1999) and Barquez and Díaz (2009). Collected specimens were deposited in the Mammal Collection of Laboratorio de Investigaciones en Evolución y Biodiversidad (LIEB, Facultad de Ciencias Naturales y Ciencias de la Salud, Universidad Nacional de la Patagonia San Juan Bosco, Sede Esquel, Argentina). Dirección de Fauna y Flora Silvestre and Subsecretaría de Conservación y Áreas Protegidas of Chubut province granted the capture permits (Disp. N² 25/2017 DFyFS-SSG; Disp. N 69/17-SsCyAP). We followed the guideline proposed by Sikes et al. (2016) for the fieldwork with mammals.

The following external measures were taken: weight (g), total length (TL), head-body length (HB), tail length (T), ear length (E), tragus length (Tr), forearm length (FA) and tibial length (Tb). Weight was taken using a Pesola scale, while all other measures were taken with digital caliper of precision $0.01 \mathrm{~mm}$. Only weight, E, FA and Tb were taken for individuals which were released (i.e. not kept as voucher specimens). Weight and FA of captured specimens were compared to published references with box-plots.

\section{Distribution analyses}

All known localities of Lasiurus villosissimus and Myotis dinellii were recorded from scientific references and museum specimens. Each locality was georeferenced using gazetteers (www.fallingrain.com) and reference maps. Point maps were generated for both species, and the following climatic values for each locality were obtained from www.worldclim.org at a resolution of $1 \mathrm{~km}^{2}$ : altitude, annual mean temperature, minimum and maximum monthly temperatures, and annual precipitation (Hijmans et al. 2005a). Also, the presence of each locality within a particular ecoregion was assigned following the scheme of Olson et al. (2001). All these analyses were done using DIVA GIS v. 7.5 (University of California, CA, USA) (Hijmans et al. 2005b) and gvSIG Desktop v 2.4.0-2850 (Valencia, Spain) (www.gvsig.org 2018). 


\section{Results}

\section{Bat survey}

Eleven specimens from six different vespertilionid species were captured in the two protected areas. Specimens of Histiotus macrotus (Poeppig 1835), Histiotus magellanicus Philippi 1866, Lasiurus varius Poeppig 1835 and Myotis chiloensis were recorded, while new southern limits were found for Lasiurus villosissimus and Myotis dinellii. Measurements for each captured species are presented in Table 1. Below we present a detailed review of these records and their biological implications.

\section{Vespertilionidae}

\section{Lasiurus villosissimus}

\section{Specimens examined $(n=1)$}

One adult female (LIEB-M 1570) captured in ANP Nant y Fall, NW Chubut, Argentina ( $43^{\circ} 11^{\prime} 25^{\prime \prime} \mathrm{S}, 71^{\circ} 28^{\prime} 19^{\prime \prime} \mathrm{W}$ ).

\section{Comments}

The specimen of Lasiurus villosissimus showed a frosty yellowish coloration, with white-tipped hairs both ventrally and dorsally. The neck and upper part of the head were markedly yellow. The rostra and outer edge of the ears were clearly dark, almost black (Figure 2A). The weight of the captured specimen was $25 \mathrm{~g}$, much larger than any other extant bat recorded in Patagonia (Figure 3). This bat was captured in a mist net at Nant y Fall stream (Figure 1), ca. $1.5 \mathrm{~m}$ above the ground. Two specimens of Histiotus macrotus (two males, LIEB-M 1617 and one released), one of Histiotus magellanicus (female, LIEB-M 1618), three of Lasiurus varius (one female, LIEB-M 1620 and two males, LIEB-M 1619 and one released) and one of Myotis chiloensis (female, LIEB-M 1621) were also captured in the same locality (see Table 1).

\section{Distribution}

A total of 140 records from 134 localities were obtained for Lasiurus villosissimus, distributed in several countries of South America (Supplementary Table 1). From the total, $62.4 \%$ records were from Argentina, 7.5\% from Bolivia, 6.8\% from Paraguay, 5.3\% from Chile, 4.5\% from Brazil and Ecuador, 3\% from Venezuela, $2.25 \%$ from Peru and Uruguay, and 1.5\% from Colombia. The northernmost locality was Bonda (Magdalena, Colombia, $11^{\circ} 14^{\prime} \mathrm{N}$ ), while the eastern and westernmost localities were Sao Paulo (Sao Paulo, Brazil, 46 ${ }^{\circ} 37^{\prime}$ W) and Santa Isabel island (Galapagos, Ecuador, $91^{\circ} 8^{\prime} \mathrm{W}$ ), respectively. The new record of ANP Nant y Fall (Chubut, Argentina, $43^{\circ} 12^{\prime} \mathrm{S}$ ) is the most austral record known to date (Figure 4A), extending the species distribution to at least $600 \mathrm{~km}$ southwest from previously known records in Argentina, and more than $225 \mathrm{~km}$ from previously known locality in Chile.

Records indicate that Lasiurus villosissimus occurs at a mean altitude of $623 \mathrm{~m}$ (above sea level), although the altitude range of the localities varied from 0 to $3373 \mathrm{~m}$. However, most localities for this species (48\%) were located below $300 \mathrm{~m}$ (Figure 5A), notoriously decreasing above $1000 \mathrm{~m}$. As to temperatures, the annual mean temperature of the localities for L. villosissimus was $17.8^{\circ} \mathrm{C}$, ranging from $-1{ }^{\circ} \mathrm{C}$ to $36^{\circ} \mathrm{C}$ of minimum and maximum monthly temperatures, respectively. Most records $(76 \%)$ were concentrated between $15^{\circ} \mathrm{C}$ and $22^{\circ} \mathrm{C}$, decreasing in

Table 1: External measures from captured specimens in ANP Nant y Fall and ANP Piedra Parada.

\begin{tabular}{|c|c|c|c|c|c|c|}
\hline Species & $\begin{array}{r}\text { L. villosissimus } \\
\qquad(\mathrm{n}=1)\end{array}$ & H. macrotus $(n=4)$ & $\begin{array}{r}\text { H. magellanicus } \\
(n=1)\end{array}$ & L. varius $(\mathrm{n}=4)$ & $\begin{array}{r}\text { M. chiloensis } \\
(n=1)\end{array}$ & $\begin{array}{r}\text { M. dinelli } \\
(n=1)\end{array}$ \\
\hline Weight (g) & 25 & $13.5(12.5-15.2)$ & 14 & $10.8(9-12)$ & 5.25 & 4.5 \\
\hline $\mathrm{TL}$ & 123 & $115(112.5-117.5)^{\mathrm{a}}$ & 121 & $90(89-91)^{a}$ & 82 & 80 \\
\hline HB & 68 & $60.7(57.5-64)^{\mathrm{a}}$ & 61 & $49(47-51)^{\mathrm{a}}$ & 48 & 46 \\
\hline $\mathrm{T}$ & 55 & $54.2(53.5-55)^{a}$ & 60 & $41(38-44)^{a}$ & 34 & 34 \\
\hline FA & 51.8 & $49.6(48.3-50.2)$ & 49.3 & $41.3(39.6-42.5)$ & 39.4 & 35.6 \\
\hline $\mathrm{E}$ & 11 & $31.5(31-31.8)$ & 24 & $11.8(11.5-12)$ & 13 & 13.5 \\
\hline $\operatorname{Tr}$ & 8 & $14.9(14.3-14.5)^{a}$ & 13 & $7.5(7-8)^{\mathrm{a}}$ & 8 & 6.45 \\
\hline $\mathrm{Tb}$ & 21.6 & $21.9(20.5-22.8)$ & 21.4 & $19.5(19.2-20)$ & 16.7 & 16.1 \\
\hline
\end{tabular}

In species were $\mathrm{n}>1$, the average, minimum and maximum values were included. andicates measures without released specimens. E, ear length; FA, forearm length; HB, head-body length; T, tail length; Tb, tibial length; TL, total length; Tr, tragus length. 


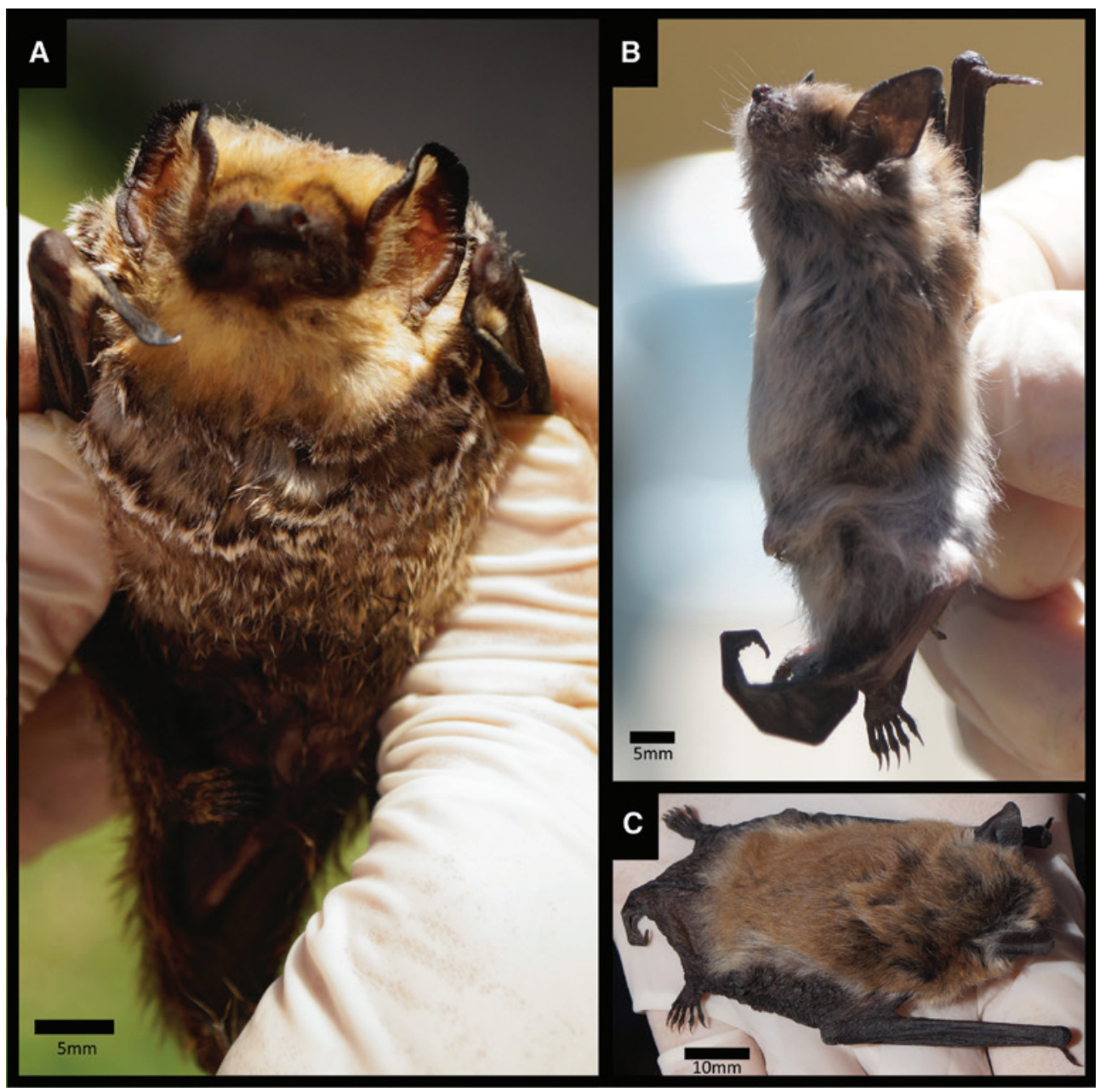

Figure 2: Photographs taken to captured specimens of L. villosissimus LIEB-M 1570 (A) and M. dinellii LIEB-M 1571 (B and C).

number toward colder and warmer areas (Figure 5B). The mean annual precipitation of the recorded localities for $L$. villosissimus was $931 \mathrm{~mm}$, ranging from 1 to $4536 \mathrm{~mm}$. Most localities (59\%) were located between 600 and $1200 \mathrm{~mm}$, notoriously decreasing toward more humid and arid areas (Figure 5C). In an ecoregional context (Olson et al. 2001), most records of $L$. villosissimus came from Humid Pampas (21\%), Southern Andean Yungas (15\%), Dry Chaco (13\%) and Espinal (7\%). The Valdivian temperate forests was the only Patagonian ecoregion with the presence of this species (4\%).

\section{Myotis dinellii}

\section{Specimens examined $(n=1)$}

One adult male (LIEB-M 1571) captured on ANP Piedra Parada, Chubut, Argentina ( $42^{\circ} 38^{\prime} 30^{\prime \prime}$ S, $70^{\circ} 05^{\prime} 59^{\prime \prime}$ W).

\section{Comments}

The specimen of Myotis dinellii showed a pale yellow dorsal pelage, with brown hairs at the base, and yellow tips. The ventral pelage was whitish, with dark hairs at the base, and lighter tips. Wing membranes and ears were darker, highly contrasting with the pelage (Figure 2B-C). This captured specimen weighed $4.5 \mathrm{~g}$, being the smallest extant Patagonian bat recorded to date (Figure 3). This bat was captured on a mist net, ca. $2 \mathrm{~m}$ above the ground outside a large cave which was presumably used as a roost (Figure 1). Two specimens of Histiotus macrotus (two males, LIEB-M 1616 and one released) were also captured in the same place (see Table 1).

\section{Distribution}

A total of 167 records from 142 different localities were recorded for Myotis dinellii distributed in Argentina, Bolivia and Brazil (Supplementary Table 2). Of the total, 

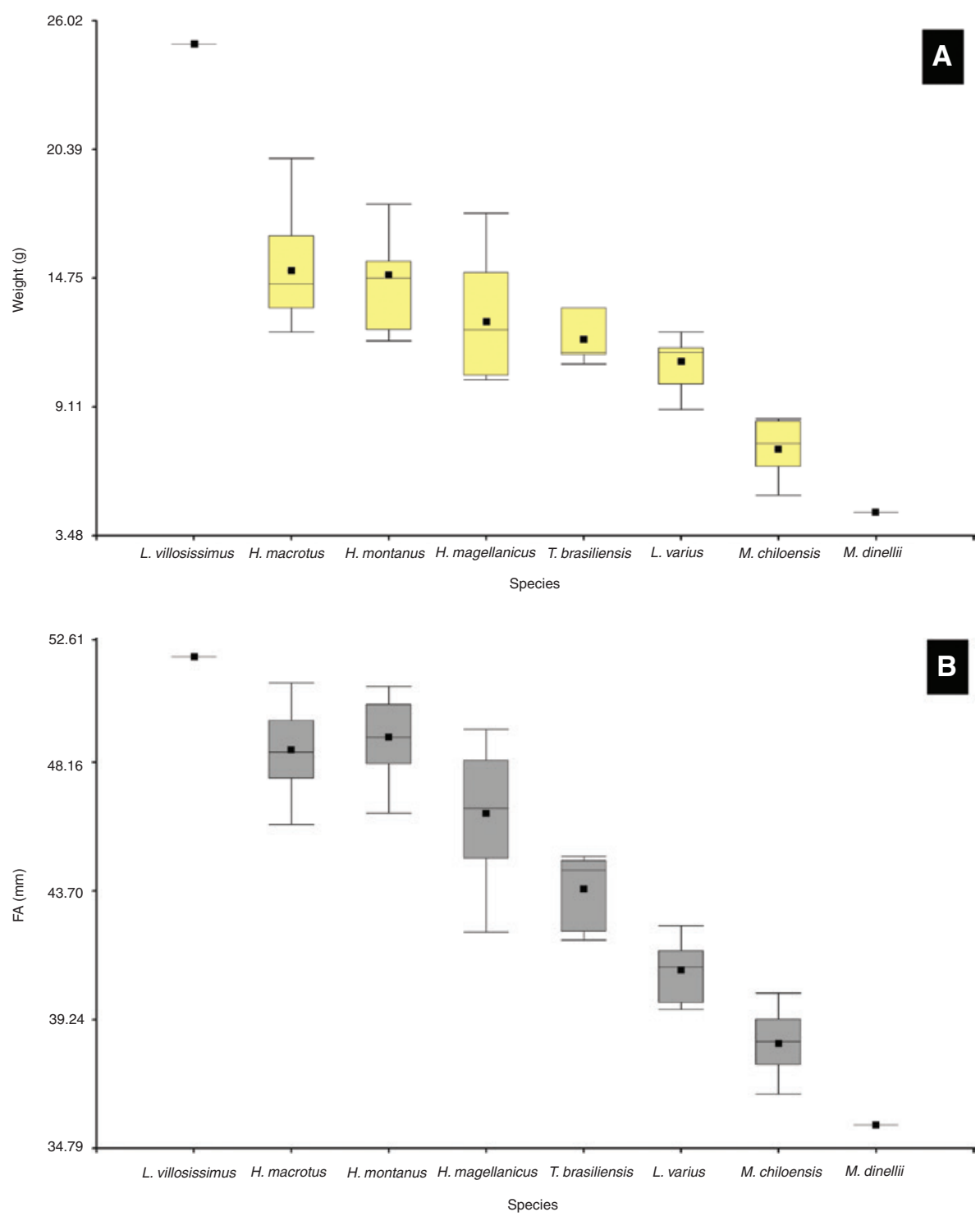

Figure 3: Box-plots of weight (A) and forearm length (B) indicating size limits of Patagonian bat species. References taken from Giménez (2010, 2014), Giménez et al. (2012).

90\% came from Argentina, 6.4\% from Bolivia and 3.6\% from Brazil. The northernmost locality recorded to date

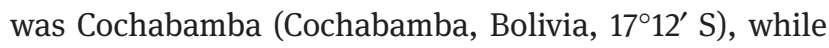
the easternmost locality was Pedras Grandes (Santa Catarina, Brazil, $\left.49^{\circ} 15^{\prime} \mathrm{W}\right)$. The new record presented here from ANP Piedra Parada (Chubut, Argentina, $42^{\circ} 38^{\prime} 30^{\prime \prime}$ $\mathrm{S}, 70^{\circ} 05^{\prime} \mathrm{W}$ ) is the western and southernmost recorded locality to date, extending the species distribution in 445 km (Figure 4B).

The mean altitude of the recorded localities of Myotis dinellii was $938 \mathrm{~m}$, ranging from 0 to $4469 \mathrm{~m}$, notoriously decreasing above $1500 \mathrm{~m}$ (Figure 5D). However, most localities (26\%) were found between 300 and $600 \mathrm{~m}$, and $82 \%$ were recorded between 0 and
$1300 \mathrm{~m}$. The mean annual temperature for the species localities had an average of $17.1^{\circ} \mathrm{C}$, ranging from $-9^{\circ} \mathrm{C}$ to $35^{\circ} \mathrm{C}$ of minimum and maximum monthly temperatures. Most records (85\%) were found between $14^{\circ} \mathrm{C}$ and $20^{\circ} \mathrm{C}$ of the annual mean temperature, decreasing toward colder areas (Figure 5E). The mean annual precipitation for records of $M$. dinellii was $625 \mathrm{~mm}$, ranging from 147 to $2999 \mathrm{~mm}$, with the majority of localities (92\%) found between 147 and $1000 \mathrm{~mm}$, decreasing toward more humid areas (Figure 5F). In an ecoregional context (Olson et al. 2001), most records for this species were located in Dry Chaco (35\%), followed by Southern Andean Yungas (18\%), Espinal, and High Monte (11\% each) and Low Monte (6\%). 


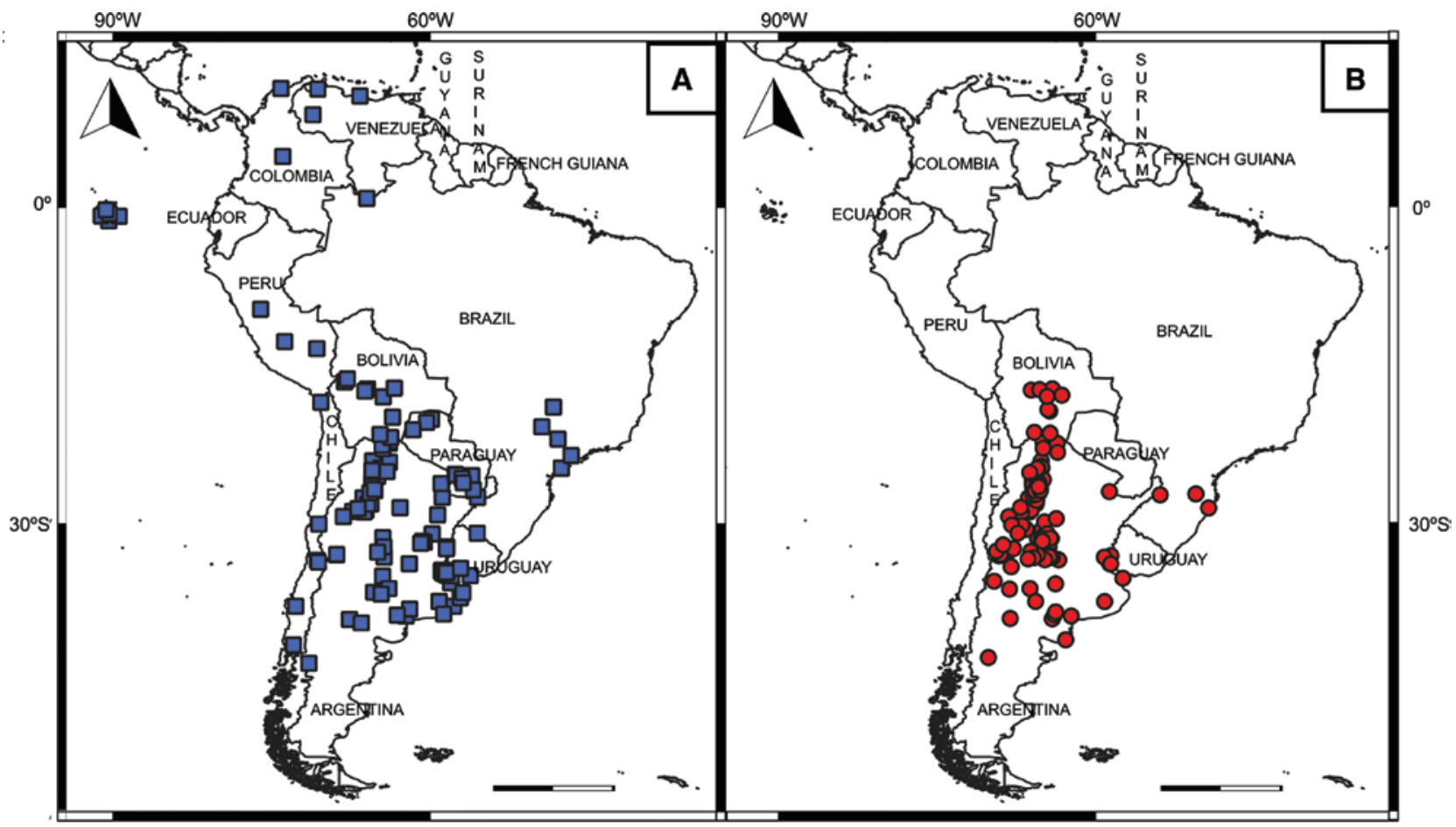

Figure 4: Recorded localities analyzed in distribution analysis for L. villosissimus (A, blue squares) and $M$. dinellii (B, red dots). (1) ANP Nant y Fall and (2) ANP Piedra Parada. Scale (black and white bar) $=1000 \mathrm{~km}$.
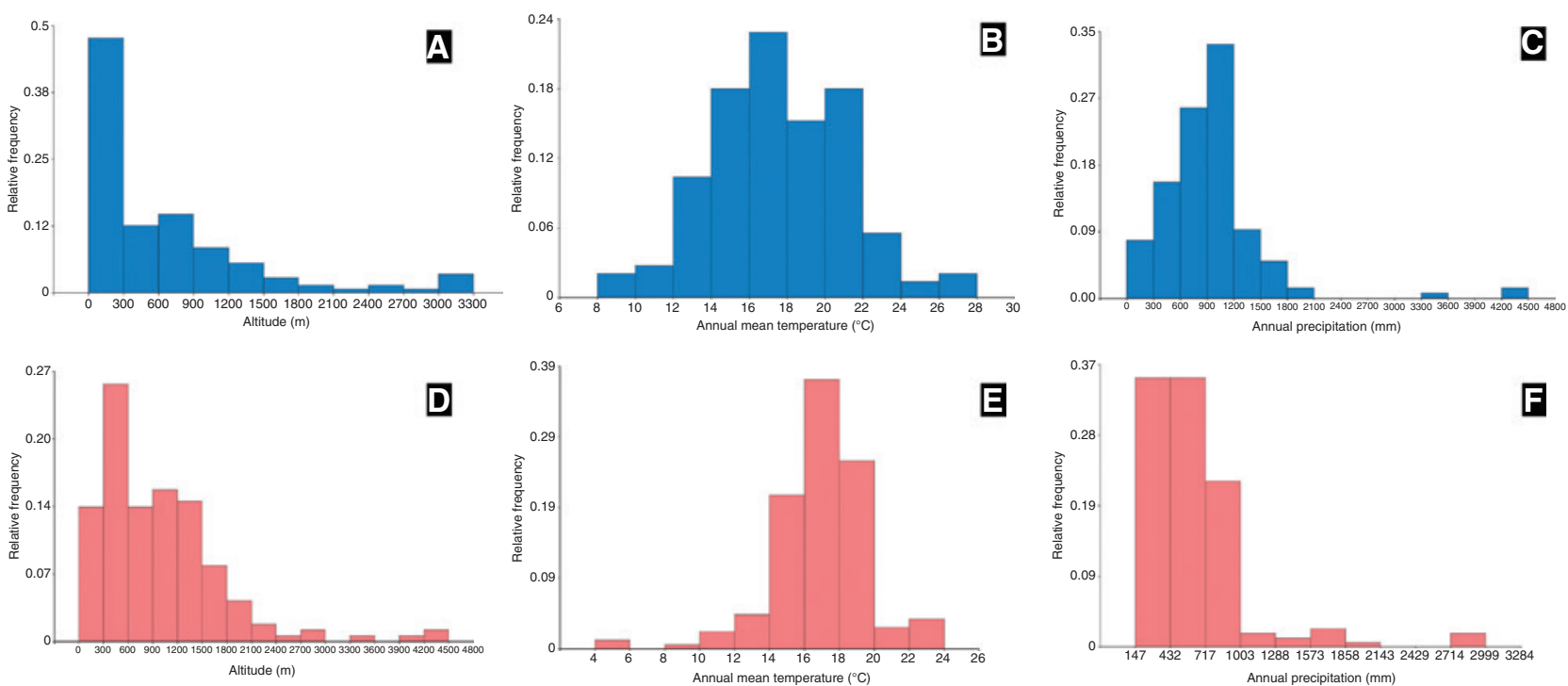

Figure 5: Climatic histograms on the basis of climatic variables for L. villosissimus and $M$. dinellii of altitude (A, D), annual mean temperature (B, E) and annual precipitation (C, F), respectively.

\section{Discussion}

Latitudinal differences between tropical and extratropical zones have long been acknowledged as the main cause for the difference in bat species richness and density in America (Willig and Selcer 1989, Stevens
2004). Different bats respond to latitude in different ways: Phyllostomidae increase their diversity toward the Equator, while Vespertilionidae are thought to achieve their highest species richness at mid-latitudes, decreasing toward both lower and higher latitudes, and Molossidae show a slower increase in species richness 
with decreasing latitude (Willig and Selcer 1989). In consequence, Patagonian bats are mostly represented by vespertilionid species (Giménez 2014). The main factors that condition their occurrence in temperate zones like Patagonia are the availability of resources and roosts. Among bats living in the same latitudinal bands, resource partitioning has been proposed as the main factor allowing their coexistence: feeding on different food items (i.e. fruit, nectar, insects), at different hours and/or at different flight altitudes (McNab 1982). Food habits are related to the basal metabolic rate, in a way that insectivorous bats living at high latitudes of South America are expected to show low metabolic rates and a poor thermoregulatory capacity (McNab 1969). To cope with this poor thermoregulatory capacity and the lack of food resources (i.e. flying insects) during much of the year, bats at their distribution extremes (e.g. cold zones as Patagonia) may enter into torpor, display clustering behavior and/or have heavy insulation (McNab 1969), or simply migrate to other areas (McNab 1982, Pearson and Pearson 1989, Stevens 2004). Likewise, the availability of suitable roosts may limit their geographic occurrence as well, because they are fundamental for mating, hibernating and rearing the young (Kunz and Lumsden 2003). In turn, roost selection can be determined by the physiological demands of the adults or young (Findley 1993).

Some studies in Patagonia presented new limits of distribution for bats (Koopman 1982, Dabbene 1902, Barquez et al. 2013, Udrizar Sauthier et al. 2013, Díaz et al. 2017), but lacking the focus of the importance of austral limits of distribution. Here, we extend the latitudinal range of Lasiurus villosissimus. Its presence in such a southern locality might be explained by a migratory behavior, as in other lasiurines such as Lasiurus cinereus and Lasiurus borealis in North America (Shump and Shump 1982a,b, Cryan 2003). As larger animals lose more heat than smaller ones in absolute terms (McNab 2010), we propose that it is unlikely that Patagonian ecoregions host such a large bat ( $25 \mathrm{~g}$ ) all year round, depending exclusively on flying insects, a resource that exhibits great fluctuations between seasons (Mazía et al. 2006, Ruggiero et al. 2009). The new record for Nant y Fall is not only the southernmost locality to date, but is also the upper size limit of any recorded bat in Patagonia, weighting $25 \mathrm{~g}$ and with an FA of $51.8 \mathrm{~mm}$. Prior to this work, the largest ones were Histiotus macrotus, weighing $14.35 \mathrm{~g}$ (12.5-18 g) with an FA of $48.1 \mathrm{~mm}$, and Histiotus montanus weighing 14.87 $\mathrm{g}$ (12-18 g) with an FA of $49.01 \mathrm{~mm}$ (taken from Giménez 2010, 2014). Concomitant with its large size, L. villosissimus displays a cranial morphology often associated with a durophagous diet (see Giménez and Giannini 2011, 2016), representing a morphotype not likely to overlap with any other extant Patagonian bat.

As stated earlier, lower densities as those occurring at distributional extremes might also be the reason why this species was not recorded before, even after 10 years of continuous bat surveys using mist nets in northwestern Chubut province (see Giménez 2010, 2014, Giménez et al. 2012). However, we believe it is likely that the species might be found south of this location, given that the Valdivian temperate forests extend continuously to ca. $47^{\circ} \mathrm{S}$ (Olson et al. 2001). In comparison, other lasiurine species such as Lasiurus cinereus is widely distributed in North America, extending up to ca. $50^{\circ} \mathrm{N}$, near the limit of trees in Canada (Shump and Shump 1982b). The widespread localities of Lasiurus villosissimus throughout many ecoregions suggests a generalist species, at least regarding its climatic tolerance. However, our results show that even with a wide range of extreme climatic values, the species is mostly found at low altitudes, warm and humid areas, consistent with the ecoregions where most records come from. Likewise, more favorable climatic areas might also be related to the larger abundance of specimens, increasing the amount of records in more suitable areas. It is well known that other Lasiurus species are mostly solitary and use trees as roosting sites (Mann Fischer 1978, Shump and Shump 1982b), which could explain its presence in forested ecosystems. This could be an indication that the polar limits to vespertilionid distribution could be directly related to the limits of forest areas in both Eurasia and North America, as a need for roosting sites (McNab 1982).

We also extended the limits for Myotis dinellii, representing the second record for the species in the Patagonian steppe ecoregion. Chubut province hosts two Myotis species again, given the recent proposal of Myotis aelleni Baud 1979 being a junior synonym of Myotis chiloensis (Novaes et al. 2018b). This new record represents the lower size limit known to date for any extant Patagonian mammal, weighing $4.5 \mathrm{~g}$ with an FA of $35.6 \mathrm{~mm}$. Prior to this work, the smallest one recorded was $M$. chiloensis weighing $7.6 \mathrm{~g}$ (5.25-8.6 g) with an FA of $38.7 \mathrm{~mm}$ (see Table 1 and Giménez et al. 2012). As small insectivorous bats show poor thermoregulatory capacity and as food resources are highly seasonal, we believe it is likely that this species hibernates to survive the harsh winter Patagonian period, but this should be further tested. However, this behavior has been extensively documented in species of the genus Myotis such as Myotis daubentonii, Myotis lucifugus, Myotis myotis or Myotis sodalis (Clawson et al. 1980, Kokurewicz 2004, Wojciechowski et al. 2006, Boyles et al. 2007). Particularly in Patagonia, M. chiloensis has 
been recorded to be able to enter in torpor periods (Mann Fischer 1978, Bozinovic et al. 1985).

Most records of Myotis dinellii were concentrated in arid zones, which may be because the species prefers such environments, or because of a greater sampling effort in these particular areas. In Córdoba province (Argentina), this species was associated with areas where mountains prevail, because they have more environmental heterogeneity and available roosting sites (Castilla et al. 2013). In these areas, $M$. dinellii was related to caverns/caves or mines and anthropic buildings used as roosts (Tiranti Paz and Torres Martínez 1998, Castilla et al. 2013). Our specimen of $M$. dinellii agrees with this description, as we caught this specimen at the exit of a large cavern in the ANP Piedra Parada. Likewise, although the little yellow bat was found to spread from ca. $17^{\circ} \mathrm{S}$ to ca. $43^{\circ} \mathrm{S}$ in South America, records were not evenly distributed, but concentrated in dry and temperate/warm areas, with elevations lower than $1800 \mathrm{~m}$. The Patagonian steppe ecoregion extends continuously to ca. $54^{\circ} \mathrm{S}$ (Olson et al. 2001). We believe it is likely that the species might be found south of this location. However, this must be confirmed with new studies.

As a conclusion, in this work we reported new records for Patagonian bats and extended the austral limit of distribution for two vespertilionid species, Lasiurus villosissimus and Myotis dinellii. The big hoary bat L. villosissimus was recorded as the largest bat inhabiting Patagonia, relating it as a bat mainly of low, humid and temperate/ warm areas. The little yellow bat $M$. dinellii, instead, is the smallest bat recorded in Patagonia to date, also extending its known distribution to the Patagonian steppe mainly in dry, mid-altitude and temperate/warm areas. This information is important not only due to the gaps in knowledge about bats at the extreme of their distribution, but also for the conservation of the species, given the recent advances of wind farms (Oliva et al. 2007, Giralt 2011, Garrido et al. 2016) and its relation with bat fatalities (Barclay et al. 2007, Rydell et al. 2010, Rodriguez-Durán and FelicianoRobles 2015), highlighting the importance of protected areas in Patagonia.

Acknowledgments: This work was possible thanks to a scholarship from provincia del Chubut granted to ALG (Beca Puente, Res. SCTeIP no. 11). Dirección de Fauna y Flora Silvestre and Subsecretaría de Conservación y Áreas Protegidas of Chubut province kindly granted the capture permits (Disp. no. 25/2017 DFyFS-SSG; Disp. no. 69/17-SsCyAP). We acknowledge the support from Agencia Nacional de Promoción Científica y Tecnológica (PICT 2016-0238 granted to MIS). We are grateful to the park rangers from ANPs Nant y Fall and Piedra Parada, particularly to Gabriela Tavella for the help during the fieldwork. Gabriel Martin helped with his valuable comments and English grammar. The manuscript was improved by the valuable comments of the editor and two anonymous reviewers.

\section{References}

Aguirre, L.F., L. Lens, R. van Damme and E. Matthysen. 2003. Consistency and variation in the bat assemblages inhabiting two forest islands within a neotropical savanna in Bolivia. J. Trop. Ecol. 19: 367-374.

Baird, A.M., J.K. Braun, M.A. Mares, J.C. Morales, J.C. Patton, C.Q. Tran and J.W. Bicham. 2015. Molecular systematic revision of tree bats (Lasiurini): doubling the native mammals of the Hawaiian Islands. J. Mammal. 96: 1255-1274.

Baird, A.M., J.K. Braun, M.D. Engstrom, A.C. Holbert, M.G. Huerta, B.K. Lim, M.A. Mares, J.C. Patton and J.W. Bickham. 2017. Nuclear and mtDNA phylogenetic analyses clarify the evolutionary history of two species of native Hawaiian bats and the taxonomy of Lasiurini (Mammalia: Chiroptera). PLoS One 12: e186085.

Barclay, R.M.R., E.F. Baerwald and J.C. Gruver. 2007. Variation in bat and bird fatalities at wind energy facilities: assessing the effects of rotor size and tower height. Can. J. Zool. 85: 381-387.

Barquez, R.M. 2006. Orden Chiroptera. In: (R.M. Barquez, M.M. Díaz and R.A. Ojeda, eds.) Mamíferos de Argentina, Sistemática y Distribución. Sociedad Argentina para el Estudio de los Mamíferos, Tucumán. pp. 56-86.

Barquez, R.M. and M.M. Díaz. 2009. Los murciélagos de Argentina: clave de identificación. Publicación Especial $N^{\circ}$ 1, Programa de Conservación de los Murciélagos de Argentina, Ediciones Magna, Tucumán. pp. 80.

Barquez, R.M., N.O. Giannini and M.A. Mares. 1993. Guide to the bats of Argentina. Oklahoma Museum of Natural History, Norman, OK, USA. pp. 119.

Barquez, R.M., J.K. Braun and M.A. Mares. 1999. The bats of Argentina. Special Publications Museum of Texas Tech University, number 42. Lubbock, TX, USA. pp. 275.

Barquez, R.M., M.N. Carbajal, M. Failla and M.M. Díaz. 2013. New distributional records for bats of the Argentine Patagonia and the southernmost known record for a molossid bat in the world. Mammalia 77: 119-126.

Baud, F.J. 1979. Myotis aelleni, nov. sp., chauve-souris nouvelle d'Argentine (Chiroptera: Vespertilionidae). Rev. Suisse Zool. 86: 267-278.

Boyles, J.G., M.B. Dunbar, J.J. Storm and V. Brack. 2007. Energy availability influences microclimate selection of hibernating bats. J. Exp. Biol. 210: 4345-4350.

Bozinovic, F., L.C. Contretas, M. Rosenmann and J.C Torres-Mura. 1985. Bioenergética de Myotis chiloensis (Quiroptera: Vespertilionidae). Rev. Chi. Hist. Nat. 58: 39-45.

Brown, J.H. 2003. Macroecología. Fondo de Cultura Económica, Mexico. pp. 397.

Burkart, R., N.O. Bárbaro, R.O. Sánchez and D.A. Gómez. 1999. Ecoregiones de la Argentina. Presidencia de la Nación, Secretaría de Recursos Naturales y Desarrollo Sustentable. Programa 
Desarrollo Institucional Ambiental, Componente Política Ambiental, Buenos Aires. pp. 43.

Cabrera, A.L. 1958. Catálogo de los Mamíferos de América del Sur. Revista del Museo Argentino de Ciencias Naturales "Bernardino Rivadavia". Instituto Nacional de Investigación de las Ciencias Naturales, Buenos Aires. pp. 307.

Castilla, C.M., R. Torres and M.M. Díaz. 2013. Murciélagos de la provincia de Córdoba, Argentina: riqueza y distribución. Mastozool. Neotrop. 20: 243-254.

Clawson, R.L., R.K. Laval, M.L. Laval and W. Caire. 1980. Clustering behavior of hibernating Myotis sodalis in Missouri. J. Mammal. 61: 245-253.

Cox, B.C. and P.D. Moore. 2005. Biogeography. An ecological and evolutionary approach. Seventh edition. Blackwell Publishing, Oxford. pp. 428.

Cryan, P.M. 2003. Seasonal distribution of migratory tree bats (Lasiurus and Lasionycteris) in North America. J. Mammal. 84: 579-593.

Dabbene, R. 1902. Fauna Magallánica. Mamíferos y aves de la Tierra del Fuego e islas adyacentes. II. Mamíferos. An. Mus. Nac. Buenos Aires 3: 348-351.

Díaz, M.M., S. Solari, L.F. Aguirre, L.M.S. Aguiar and R.M. Barquez. 2016. Clave de identificación de los murciélagos de Sudamérica. Publicación Especial N 2, PCMA (Programa de Conservación de los Murciélagos de Argentina), Tucumán. pp. 160.

Díaz, M.M., A. Valenzuela, S. Sturzenbaum and R.M. Barquez. 2017. New records of bats (Chiroptera) from Santa Cruz province (Argentina) and the southernmost record of Lasiurus varius (Poeppig, 1835) for Argentina. Check List 13: 397-401.

Dinerstein, E., D.M. Olson, D.J. Graham, A.L. Webster, S.A. Primm, M.P. Bookbinder and G. Ledec. 1995. Una evaluación del estado de conservación de las Eco-regiones terrestres de América Latina y el Caribe. Publicado en colaboración con el Fondo Mundial para la Naturaleza. Banco Mundial, Washington DC. pp. 129.

Findley, J.S. 1993. Bats. A community perspective. Cambridge University Press, New York. pp. 167.

Fitzinger, L.J. 1870. Kritische durchsicht der ordnung der flatterthiere oder handflüger (Chiroptera). V. Abtheilung. Sitzungsber. Kaiserl. Akad. Wiss. Wien. 62: 353-438.

Garreaud, R.D., M. Vuille, R. Compagnucci and J. Marengo. 2009. Present-day South American climate. Palaeogeogr. Palaecol. 281: 180-195.

Garrido, S., A. Lalouf and G. Santos. 2016. Energía eólica de alta potencia en Argentina. Análisis socio-técnico de su trayectoria (1990-2015). XI Jornads Latino-Americanas de Estudos Sociais da Ciéncia e da Tecnologia. Esocite, Curitiba. pp. 18.

Gaston, K.J. 2003. The structure and dynamics of geographic ranges. Oxford University Press, Oxford. pp. 280.

Geoffroy St.-Hilaire, E. 1806. Mémoire sur le genre et les espèces de Vespertilion, l'un des genres de la famille des chauves-souris. Ann. Mus. Hist. Nat. Paris 8: 187-205.

Geoffroy St.-Hilaire, I. 1824. Memoire sur une Chauve-Souris americaine, formant une nouvelle espece dans le genre Nyctinome. Ann. Sci. Nat. Paris. 1: 337-347.

Gervais, P. 1856. Deuxième mémoire. Documents zoologiques pour servir a la monographie des cheiroptères sud-américains. In: (F. Castelnau, ed.) Animaux nouveaux ou rares recueillis pendant l'expédition dans les parties centrales de l'Amérique du Sud, de Rio de Janeiro a Lima, et de Lima au Para; exécutée par ordre du gouvernement français pendantles années 1843 a 1847, sous la direction du comte Francis de Castelnau, Paris. pp. 1-116.

Giménez, A.L. 2010. Primeros registros de Histiotus macrotus (Chiroptera: Vespertilionidae) en la Provincia del Chubut, Argentina. Mastozool. Neotrop. 17: 375-380.

Giménez, A.L. 2014. Ecología comparativa de los ensambles de murciélagos de Patagonia central. Ph.D Thesis, Facultad de Ciencias Naturales e Instituto Miguel Lillo. Universidad Nacional de Tucumán, Argentina.

Giménez, A.L. and N.P. Giannini. 2011. Morphofunctional and geographic segregation among species of lasiurine bats (Chiroptera: Vespertilionidae) from the South American Southern Cone. Mammalia 75: 173-179.

Giménez, A.L. and N.P. Giannini. 2016. The endemic Patagonian vespertilionid assemblage is a depauperate ecomorphological vicariant of species-rich neotropical assemblages. Curr. Zool. 63: 495-505.

Giménez, A.L., N.P. Giannini, M.I. Schiaffini and G.M. Martin. 2012. New records of the rare Histiotus magellanicus (Chiroptera, Vespertilionidae) and other bats from Central Patagonia, Argentina. Mastozool. Neotrop. 19: 213-224.

Giralt, C. 2011. Energía eólica en Argentina: un análisis económico del derecho. Letras Verdes. Rev. Latinoamericana Est. Socioamb. 9: 65-88.

Gray, J.E. 1831. Descriptions of some new genera and species of bats. Zool. Misc. 1: 37-38.

Hijmans, R.J., S.E. Cameron, J.L. Parra, P.G. Jones and A. Jarvis. 2005a. Very high resolution interpolated climate surfaces for global land areas. Int. J. Climatol. 25: 1965-1978.

Hijmans, R.J., L. Guarino, P. Mathur, A. Jarvis, E. Rojas, M. Cruz and I. Barrantes. 2005b. DIVA-GIS, version 5.2.

Humpries, M.M., D.W. Thomas and J.R. Speakman. 2002. Climatemediated energetic constraints on the distribution of hibernating mammals. Nature 418: 313-316.

Kaup, J. 1829. Skizzirte Entwickelungs-Geschichte und Natürliches System der Europäischen Thierwelt. Theil 1. Carl Wilhelm Leske, Darmstadt \& Leipzig. pp. 204.

Kokurewicz, T. 2004. Sex and age related habit selection and mass dynamics of Daubenton's bats Myotis daubentonii (Kuhl, 1817) hibernating in natural conditions. Acta Chiropterol. 6: 121-144.

Koopman, K.F. 1982. Biogeography of the bats of South America. In: (M.A. Mares and H.H. Genoways, eds.) Mammalian biology in South America. University of Pittsburgh, Pittsburgh, PN. pp. 273-302.

Kunz, T.H. and L.F. Lumsden. 2003. Ecology of cavity and foliage roosting bats. In: (T.H. Kunz and M.B. Fenton, eds.) Bat ecology. The University of Chicago Press, Chicago and London. pp. 3-90.

LaVal, R.K. 1973. A revision of the Neotropical bats of the genus Myotis. Nat. Hist. Mus Los Angeles County Sci. Bull. 15: 1-54.

León, R.J.C., D. Bran, M. Collantes, J.M. Paruelo and A. Soriano. 1998. Grandes unidades de vegetación de la Patagonia extra andina. Ecol. Austral 8: 125-144.

Lesson, R.-P. 1826. Mammifères nouveaux ou peu connus, décrits et figures dans l'Atlas zoologique du Voyage autour du monde de la corvette le Coquille. Bull. Scienc. Nat. Géol. 8: 95-96.

Mackey, B.G. and D.B. Lindenmayer. 2001. Towards a hierarchical framework for modelling the spatial distribution of animals. J. Biogeogr. 28: 1147-1166. 
Mancini, M.V., M.M. Paez, A.R. Prieto, S. Stutz, M. Tonello and I. Vilanova. 2005. Mid-Holocene climatic variability reconstruction from pollen records (32-52 ${ }^{\circ} \mathrm{S}$, Argentina). Quatern. Int. 132: 47-59.

Mann Fischer, G. 1978. Los pequeños mamíferos de Chile, marsupiales, quirópteros, edentados y roedores. Gayana Zool. 40: 1-342.

Mazía, C.N., E.J. Chaneton and T. Kitzberger. 2006. Small-scale habitat use and assemblage structure of ground-dwelling beetles in a Patagonian shrub steppe. J. Arid Environ. 67: 177-194.

McNab, B.K. 1969. The economics of temperature regulation in Neotropical bats. Comp. Biochem. Physiol. 31: 227-268.

McNab, B.K. 1982. Evolutionary alternatives in the physiological ecology of bats. In: (T.H. Kunz, ed.) Ecology of bats. Plenum, New York, NJ. pp. 151-200.

McNab, B.K. 2010. Geographic and temporal correlations of mammalian size reconsidered: a resource rule. Oecologia 164: 13-23.

Miranda, J.M.D., I.P. Bernardi, J. Sponchiado and F.C. Passos. 2013. The taxonomic status of Myotis levis levis and Myotis levis dinellii (Mammalia: Chiroptera: Vespertilionidae). Zoologia 30: 513-518.

Monjeau, J.A., N. Bonino and S. Saba. 1994. Annotated checklist of the living land mammals in Patagonia, Argentina. Mastozool. Neotrop. 1: 143-156.

Moratelli, R. and D.E. Wilson. 2011. A new species of Myotis Kaup, 1829 (Chiroptera, Vespertilionidae) from Ecuador. Mammal. Biol. 76: 608-614.

Moratelli, R., A.L. Gardner, J.A. De Oliveira and D.E. Wilson. 2013. Review of Myotis (Chiroptera, Vespertilionidae) from northern South America, including description of a new species. Am. Mus. Novit. 3780: 1-36.

Moratelli, R., D.E. Wilson, A.L. Gardner, R.D. Fisher and E.E. Gutiérrez. 2016. A new species of Myotis from Suriname (Chiroptera, Vespertilionidae). Occ. Papers Mus. Texas Tech Univ. 65: 49-63.

Moratelli, R., D.E. Wilson, R.L.M. Novaes, K.M. Helgen and E.E. Gutiérrez. 2017. Caribbean Myotis (Chiroptera, Vespertilionidae), with description of a new species from Trinidad and Tobago. J. Mammal. 98: 994-1008.

Novaes, R.L.M., G.S.T. Garbino, V.C. Cláudio and R. Moratelli. 2018 a. Separation of monophyletic groups into distinct genera should consider phenotypic discontinuities: the case of Lasiurini (Chiroptera: Vespertilionidae). Zootaxa 4379: 439-440.

Novaes, R.L.M., D.E. Wilson, M. Ruedi and R. Moratelli. 2018b. The taxonomic status of Myotis aelleni Baud, 1979 (Chiroptera, Vespertilionidae). Zootaxa 4446: 257-264.

Oliva, R., J.R. Lescano, P. Triñanes and N. Cortez. 2007. Sistemas eólicos e híbridos - mediciones y simulaciones para su diseño teniendo en cuenta la variabilidad estacional del recurso en Patagonia. Av. Energ. Renov. Medio Ambiente. 11: 29-34.

Olson, D.M., E. Dinerstein, E.D. Wikramanayake, N.D. Burgess, G.V.N. Powell, E.C. Underwood, J.A. D’Amico, I. Itoua, H.E. Strand, J.C. Morrison, C.J. Loucks, T.F. Allnutt, T.H. Ricketts, Y. Kura, J.F. Lamoreux, W.W. Wettengel, P. Hedao and K.R. Kassem. 2001. Terrestrial ecoregions of the world: a new map of life on earth. Bioscience 51: 933-938.

Palisot de Beauvois, A.M.F.J. 1796. Catalogue raisonné du museum, de Mr. C. W. Peale, membre de la société philosophique de Pensylvanie. De l'Imprinmerie de Parent, Philadelphia, Pennsylvania. p. 42.

Paruelo, J.M., A. Beltrán, E. Jobbágy, O.E. Sala and R.A. Golluscio. 1998. The climate of Patagonia: general patterns and control on biotic processes. Ecol. Austral. 8: 85-101.

Passos, F.C., J.M.D. Miranda, I.P. Bernardi, N.Y. Kaku-Oliveira and L.C. Munster. 2010. Morcegos da Região Sul do Brasil: análise comparativa da riqueza de espécies, novos registros e atualizações nomenclaturais (Mammalia, Chiroptera). Iheringia Ser. Zool. 100: 25-34.

Pearson, O.P. and A.K. Pearson. 1989. Reproduction of bats in Southern Argentina. In: (K.H. Redford and J.F. Eisenberg, eds.) Advances in Neotropical Mammalogy. University of Florida, Gainesville, Florida. pp. 549-566.

Peters, W. 1870. Eine monographische übersicht der chiropterengattungen Nycteris und Atalapha vor. Monatsber. König. Preuss. Akad. Wiss. Berlin 1871: 900-914.

Petracci, P.F. and C.H. Perez. 1999. Nuevo registro de Lasiurus cinereus (Beauvois, 1796) (Chiroptera: Vespertilionidae) en la provincia de Río Negro. Neotropica 45: 76-76.

Philippi, R.A. 1866. Ueber ein paar neue Chilenische Säugthiere. Arch. Naturgesch. 32: 113-117.

Poeppig, E.L. 1835. Reise in Chile, Peru, und auf dem Amazonenströme während de Jahre 1827-1832. F. Fleischer, Leipzig. pp. 466.

Rydell, J., L. Bach, M.-J. Dubourg-Savage, M. Green, L. Rodrigues and A. Hedenström. 2010. Bat mortality at wind turbines in northwestern Europe. Acta Chiropterol. 12: 261-274.

Rodríguez-Durán, A. and W. Feliciano-Robles. 2015. Impact of wind facilities on bats in the Neotropics. Acta Chiropterol. 17: 365-370.

Ruggiero, A., P. Sackmann, A.G. Farji-Brener and M. Kun. 2009. Beetle abundance-environment relationships at the Subantarctic-Patagonian transition zone. Insect. Conserv. Diver. 2: 81-92.

Shump, K.A. Jr. and A.U. Shump. 1982a. Lasiurus borealis. Mammal. Species 183: 1-6.

Shump, K.A. Jr. and A.U. Shump. 1982b. Lasiurus cinereus. Mammal. Species 185: 1-5.

Sikes R.S. and the Animal Care and Use Committee of the American Society of Mammalogists. 2016. 2016 Guidelines of the American Society of Mammalogists for the use of wild mammals in research and education. J. Mammal. 97: 663-688.

Simmons, N.B. 2005. Order Chiroptera. In: (D.E. Wilson and D.M. Reeder, eds.) Mammals Species of the World: a taxonomic and geographic references. Third edition. The Johns Hopkins University Press, Baltimore, MD, USA. pp. 312-529.

Soberón, J. and A.T. Peterson. 2005. Interpretation of niches of fundamental ecological niches and species' distributional areas. Biodivers. Inf. 2: 1-10.

Stevens, R.D. 2004. Untangling latitudinal richness gradients at higher taxonomic levels: familial perspectives on the diversity of New World bat communities. J. Biogeogr. 31: 665-674.

Teta, P., A.M. Abba, G.H. Cassini, D.A. Flores, C.A. Galliari, S.O. Lucero and M. Ramírez. 2018. Lista revisada de los mamíferos de Argentina. Mastozool. Neotrop. 5: 163-198.

Thomas, 0. 1902. On Azara's “chauve-souris onzieme" (Myotis ruber, Geoff.) and a new species allied to it. Ann. Mag. Nat. Hist., Ser. 7, 10: 493-494. 
Thomas, O. 1924. New South American small mammals. Ann. Mag. Nat. Hist. 13: 234-237.

Tiranti Paz, S.I. and M.P. Torres Martínez. 1998. Observations on bats of Córdoba and La Pampa provinces, Argentina. Occas. Pap. Mus. Tex. Tech Univ. 175: 1-13.

Udrizar Sauthier, D.E., P. Teta, A.E. Formoso, A. Bernardis, P. Wallace and U.F.J. Pardiñas. 2013. Bats at the end of the world: new distributional data and fossil records from Patagonia, Argentina. Mammalia 77: 307-315.

Veblen, T.H. and D.C. Lorenz. 1988. Recent vegetation changes along the forest/steppe ecotone of northern Patagonia. Ann. Assoc. Am. Geogr. 78: 93-111.

Velasco, V. and G. Siffredi. 2009. Guía para el reconocimiento de especies de los pastizales de sierras y mesetas occidentales de Patagonia. Ediciones INTA, Bariloche. pp. 188.

Waterhouse, G.R. 1839 (1840). The zoology of the voyage of H. M. S. Beagle, under the command of Captain Fitzroy, R.N., during the years 1832 to 1836. Part 2. Mammalia. Smith, Elder and Co., London. pp. 101.
Willig, M.R. and K.W. Selcer. 1989. Bat species density gradients in the New World: a statistical assessment. J. Biogeogr. 16: 189-195.

Wilson, D.E. 2007. Genus Myotis Kaup, 1929. In: (A.L. Gardner, ed.) Mammals of South America, Volume 1: Marsupials, xenarthrans, shrews, and bats. The University of Chicago Press, Chicago, IL, USA. pp. 469-481.

Wojciechowski, M.S., M. Jefimow and E. Tegowska. 2006. Environmental conditions, rather than season, determine torpor use and temperature selection in large mouse-eared bats (Myotis myotis). Comp. Biochem. Physiol. 147: 828-840.

Ziegler, A.C., F.G. Howarth and N.B. Simmons. 2016. A second endemic land mammal for the Hawaiian Islands: a new genus and species of fossil bat (Chiroptera: Vespertilionidae). Am. Mus. Novit. 3854: 1-52.

Supplementary Material: The online version of this article offers supplementary material (https://doi.org/10.1515/mammalia-20190024). 